\title{
SCANNING ELECTRON MICROSCOPY ON THE PARTIAL SWELLINGS OF MYCOBACTERIUM LEPRAEMURIUM APPEARED DURING CULTIVATION IN CELL-FREE LIQUID NC-5 MEDIUM
}

\author{
ZENSAKU YOSHII \\ Department of Microbiology, Yamaguchi University School \\ of Medicine, Ube, 755, Japan \\ MASAHIRO NAKAMURA \\ Department of Microbiology, Kurume University School \\ of Medicine, Kurume, 830, Japan
}

(Received for publication March 1, 1976)

\begin{abstract}
Partial swellings of cell bodies of Mycobacterium lepraemurium cultivated in the NC-5 medium were observed with a scanning electron microscope. Shapes, sizes, locations, dividing and budding forms of the partial swellings were described. The partial swelling was regarded as the growing phase of a stage in the life history or life cycle of Mycobacterium lepraemurium. Similarity of the swelling to a bacterial spore was also noticed, however, further investigation is required for the determination of its microbial significance.
\end{abstract}

\section{INTRODUCTION}

The primary cultivation of Mycobacterium lepraemurium in the cellfree liquid medium was successful by Nakamura (1972). Since then, further studies on the cultivation of the bacterium were consecutively published by the same author (Nakamura, 1973, 1974). Glass slide cultures of the bacterium in the NC-5 medium were observed with a scanning electron microscope (SEM) and their growth features were confirmed by Yoshii and Nakamura (1973, 1974, 1975), and the suspension culture in the same medium was also investigated with a transmission electron micro- scope (TEM) by Nakamura and coworkers (1975).

Thus several phases and shapes of the bacillar cell bodies with elongation, dividing and budding were observed in the NC-5 medium, and cultivation of the bacterium was confirmed to be successful as the primary cultivation with multiplication of bacterial cells under transmission electron microscopy as well as scanning electron microscopy.

In the series of scanning electron microscopy of Mycobacterium lepraemurium cultivated in the NC-5 medium, various types of partial swellings of cell bodies were also recognized. In the present paper, details of them are 
described and their microbiological significance is also discussed.

\section{MATERIALS AND METHODS}

\section{Strain used}

The Hawaiian strain of Mycobacterium lepraemurium (M 56) was used. This strain has been maintained in Nakamura's laboratory for several years by subcutaneous inoculation into mice.

\section{Cultivation and observation}

Cultivation procedures, specimen preparation methods and scanning electron microscopy are the same as the previous papers (Nakamura, 1973, 1974 ; Yoshii and Nakamura, 1973, 1974).

\section{OBSERVATIONS}

By observing and photography of the specimens in the SEM, partial swellings of bacillar cell bodies were found and described under the following conditions during the several incubation periods.

Most of bacillar cells showed granular features in their cell bodies before incubation (Fig. 1), and partial swellings such as shown in other figures were seldom seen. After 4 weeks of incubation period, many varieties of partial swellings were frequently seen as shown in Figs. $2 \sim 6$.

The partial swellings can be classified into three major types, such as the round type (Figs. 2, 3-A, 9-B and 11-A), the ellipsoidal type (Figs. 4, 5, 7-B, -C, 8-A, -B, 9-A, 10-A, -B, 11-B, 12, 13-A, $-\mathrm{B},-\mathrm{C}$ and $14-\mathrm{A},-\mathrm{B},-\mathrm{C})$ and other miscellaneous type (Figs. 3-B, 6-A, -B, -C, 7-A and 9-C). Number of swelling in an individual cell was usually counted as a single (Figs. $2 \sim 8$ ), however, double swelling:s sometimes could be seen in one cell (Figs. 9 and 10).
Sizes of them are also variable, that is, the round type was estimated in the range of $1.0 \times 0.7-1.5 \times 1.5 \mu \mathrm{m}$, the ellipsoidal type was in the range of $1.0 \times 0.7$ $-2.0 \times 1.2 \mu \mathrm{m}$, respectively.

Location of the partial swellings was also classified into four major types, such as the terminal type (Fig.s. 2, 3-B, $4,5,6,9-\mathrm{A},-\mathrm{B}, 11$ and $13-\mathrm{A},-\mathrm{B})$, the subterminal type (Figs. 7-B, -C, 8-B and $10-\mathrm{A},-\mathrm{B})$, the central and subcentral types (Figs. 8-A, 10-B, 12, 13-C and 14-A, $-\mathrm{B},-\mathrm{C})$.

Several other features were also recognized as follows :

In some figures, several dividing images, such as a division between cell body and partial swelling (Fig. 4), and between two terminal swellings (Fig. 13) could be seen. One of the swellings of the round type shown in Fig. 3 looked like a free granule. A swelling was covered with an envelope in some figure (Fig. 6-C).

Two types of images of projection or protrusion from the swollen part of cell body sometimes could be seen. One of them was a type of the side protrusion (Figs. 8-B and 14) and the other was of the extensive projection (Figs. 11 and 12). In these cases, most of swellings usually showed an ellipsoidal form.

Details of observations were explained in each figure and summarized in Table 1.

\section{DISCUSSION}

Partial swelling of bacterial cell body was rarely reported among acid-fast bacteria, and two reports can only be seen in Mycobacterium marianum (Penso, 1964) and Mycobacterium lepraemurium (Nakamura et al., 1975). The significance of swelling is also very difficult to be interpretated (Penso, 1964; Nakamura et al., 1975). 
TABLE 1

Morphological features of partial swellings of Mycobacterium lepraemurium cultivated in the NC-5 medium under scanning electron microscopy

\begin{tabular}{|c|c|c|c|c|c|}
\hline Fig. no. & Shape & Size $(\mu \mathrm{m})$ & Location & Remarks & $\begin{array}{l}\text { Incubation } \\
\text { (week) }\end{array}$ \\
\hline 1 & Granular cell & Varieties & & $\begin{array}{l}\text { Common features } \\
\text { of bacilli in vivo }\end{array}$ & 0 \\
\hline 2 & Long round & $1.0 \times 0.7$ & $\mathrm{~T}$ & $\begin{array}{l}\text { At the elongated } \\
\text { cell end }\end{array}$ & $4 \mathrm{w}$ \\
\hline $3\left\{\begin{array}{l}\mathrm{A} \\
\mathrm{B}\end{array}\right.$ & $\begin{array}{l}\text { Round } \\
\text { Miscellaneous }\end{array}$ & $\begin{array}{l}1.2 \times 1.2 \\
1.4 \times ?\end{array}$ & $\begin{array}{c}\text { Free? } \\
\quad ?\end{array}$ & $\begin{array}{l}\text { Free granule? } \\
\text { Irregular }\end{array}$ & $6 \mathrm{w}$ \\
\hline 4 & Ellipsoidal & $2.0 \times 1.2$ & $\mathrm{~T}$ & $\begin{array}{l}\text { Septum between } \\
\text { neighboring cell }\end{array}$ & $8 \mathrm{w}$ \\
\hline 5 & Ellipsoidal & $1.5 \times 1.0$ & $\mathrm{~T}$ & Extensive protrusion & $10 \mathrm{w}$ \\
\hline 6 & $\begin{array}{l}\text { Four miscel- } \\
\text { laneous swellings }\end{array}$ & Varieties & $\mathrm{T}$ & $\begin{array}{l}\text { Swelling-C is } \\
\text { within envelope }\end{array}$ & $10 \mathrm{w}$ \\
\hline $7\left\{\begin{array}{l}\mathrm{A} \\
\mathrm{B} \\
\mathrm{C}\end{array}\right.$ & $\begin{array}{l}\text { Miscellaneous } \\
\text { Ellipsoidal } \\
\text { Ellipsoidal } \\
\end{array}$ & $\begin{array}{l}1.5 \times 1.0 \\
1.5 \times 0.8\end{array}$ & $\begin{array}{l}\text { Free } \\
\text { S. T. } \\
\text { S. T. }\end{array}$ & $\begin{array}{l}\text { Elongation of cells } \\
\text { is very remarkable }\end{array}$ & $8 \mathrm{w}$ \\
\hline $8\left\{\begin{array}{l}A \\
B\end{array}\right.$ & $\begin{array}{l}\text { Ellipsoidal } \\
\text { Ellipsoidal }\end{array}$ & $\begin{array}{l}1.0 \times 0.7 \\
1.2 \times 0.8\end{array}$ & $\begin{array}{l}\text { S. T. } \\
\text { S. T. }\end{array}$ & $\begin{array}{l}\text { In mother cell } \\
\text { In daughter cell } \\
\text { with } 3 \text { budds? }\end{array}$ & $8 \mathrm{w}$ \\
\hline $9\left\{\begin{array}{l}\mathrm{A} \\
\mathrm{B} \\
\mathrm{C}-1 \\
\mathrm{C}-2\end{array}\right.$ & $\begin{array}{l}\text { Ellipsoidal } \\
\text { Long round } \\
\text { Complex }\end{array}$ & Unestimatable & $\begin{array}{l}\mathrm{T} \\
\mathrm{T}\end{array}$ & $\begin{array}{l}\text { Elongation of cell } \\
\text { is remarkable }\end{array}$ & $4 \mathrm{w}$ \\
\hline $10\left\{\begin{array}{l}\mathrm{A} \\
\mathrm{B} \\
\mathrm{C}\end{array}\right.$ & $\begin{array}{l}\text { Ellipsoidal } \\
\text { Ellipsoidal } \\
\text { Incomplete } \\
\text { ellipsoidal }\end{array}$ & $\begin{array}{c}2.0 \times 1.0 \\
2.0 \times 1.0 \\
\text { Unestimatable }\end{array}$ & $\begin{array}{l}\text { S. T. } \\
\text { S. T. } \\
\text { C }\end{array}$ & & $6 \mathrm{w}$ \\
\hline $11\left\{\begin{array}{l}\mathrm{A} \\
\mathrm{B}\end{array}\right.$ & $\begin{array}{l}\text { Large round } \\
\text { Ellipsoidal }\end{array}$ & $\begin{array}{l}1.5 \times 1.5 \\
1.5 \times 0.7\end{array}$ & $\begin{array}{l}\mathrm{T} \\
\mathrm{S}\end{array}$ & $\begin{array}{l}\text { With extensive } \\
\text { projection }\end{array}$ & $10 \mathrm{w}$ \\
\hline 12 & Ellipsoidal & $1.8 \times 1.0$ & S. T. & In branched cell & $6 \mathrm{w}$ \\
\hline $13\left\{\begin{array}{l}A \\
B \\
C\end{array}\right.$ & $\begin{array}{l}\text { Small ellipsoidal } \\
\text { Small ellipsoidal } \\
\text { Ellipsoidal }\end{array}$ & $\begin{array}{l}0.8 \times 1.2 \\
0.5 \times 0.8 \\
2.0 \times 1.0\end{array}$ & $\begin{array}{l}\mathrm{T} \\
\mathrm{T} \\
\mathrm{C}\end{array}$ & $\begin{array}{l}\text { Connection between } \\
\mathrm{A} \text { and } \mathrm{B}\end{array}$ & $10 \mathrm{w}$ \\
\hline $14\left\{\begin{array}{l}\mathrm{A} \\
\mathrm{B} \\
\mathrm{C}\end{array}\right.$ & $\begin{array}{l}\text { Ellipsoidal } \\
\text { Ellipsoidal } \\
\text { Ellipsoidal }\end{array}$ & $\begin{array}{l}1.2 \times 2.0 \\
0.8 \times 2.0 \\
2.0 \times 1.5\end{array}$ & $\begin{array}{l}\mathrm{C} \\
\mathrm{C} \\
\mathrm{C}\end{array}$ & Side projection & $10 \mathrm{w}$ \\
\hline
\end{tabular}

Abbreviations: $\mathrm{T}=$ Terminal, $\mathrm{S} . \mathrm{T} .=$ Subterminal, $\mathrm{C}=$ Central, S.C.= Subcentral. 
The partial swellings in the present study were usually seen on the elongated cell bodies of cultured rat leprosy bacilli (Figs. 2, 7, 8, 9 and 10) and some of them sometimes had an extensive protrusion (Figs. 5 and 11-A) or a side protrusion (Figs. 8-B and 14-A) during the advanced stages of incubation, such as $8 \sim 12$ weeks. The former type from the partial swelling may be a specific form during the growing process of cell body, and the latter indicates it to be a kind of budding form from the swelling which is a mother body of budd. Because, some dividing images shown Figs. 4 and 13 are remarkably suggestive.

Appearance of partial swellings in the rat leprosy bacilli during the incubation periods proved that metabolism and life history of the bacilli must be complex even in the cell-free liquid NC-5 medium.

Similarity between partial swelling and bacterial spore suggests that the partial swelling could be a kind of durable form, however, their several characteristics such as the structural and physiological features must be investigated in comparison with those of bacterial spore.

Morphological features, such as shape, size and location of partial swellings are similar to a spheroidal aerial spore in Actinomyces (Knaysi, 1951) and some prosthecate budding bacteria (Laskin and Lechevalier, 1973).

This fact also suggests that there may be a close relationship between their lives.

\section{REFERENCES}

KNAYSI, G. (1951). Elements of bacterial cytology, 2nd ed., pp. 310-312. Comstock Pub. Co. Inc. Ithaca, New York.

Laskin, A.L. and Lechevalier, H.A. (1973). Group III. Budding, prosthecate bacteria, in Handbook of Microbiology, Vol. 1, pp. 41-42. Organismic Microbiology, CRC Press, Cleveland, Ohio.

NAKAMURA, M. (1972). Multiplication of Mycobacterium lepraemurium in cell-free medium containing $\alpha$-ketoglutaric acid and cytochrome c. J. Gen. Microbiol., 73, 193-195.

NAKAMURA, M. (1973). Multiplication of Mycobacterium lepraemurium in cell-free liquid medium. Proc. Japan Academy, 49, 42-46.

NAKAMURA, M. (1974). Quantitative multiplication of Mycobacterium lepraemurium in a cell-free liquid medium (NC-5). J. Gen. Microbiol, 82, 42-46.

Nakamura, M., Iтон,T. and Yoshil,Z. (1975). A mode of the growth of Mycobacterium lepraemurium in a cell-free liquid medium. Proc. Soc. Exp. Biol. and Med, 148, 183-186.

Penso,G. (1964). Mycobacterium marianum, in Atlas of Electron Microscopy : Biological applications, compiled by F. Scanga, Vol. 88, Figs. 134-136. Eloevier Pub. Co.

Yoshil, Z. and Nakamura, M. (1973). Scanning electron microscopy of Mycobacterium lepraemurium cultivated on the slide glass. Proc. Japan Academy, 49, 47-50.

YoshiI, Z. and Nakamura, M. (1974). Scanning electron microscopic studies on the growth features of Mycobacterium lepraemurium in cell-free medium. J. Gen. Microbiol., 83, 145-152.

YoshiI, Z. and NaKamura, M. (1975). Growth features of Mycobacterium lepraemurium cultivated in NC-5 medium. Kurume Med. J., 22, 35-56. 
All the figures are scanning electron micrographs of Mycobacterium lepraemurium cultivated on the glass slide in a cell-free liquid medium (NC-5 medium) by Nakamura in 1973 and 1974 .

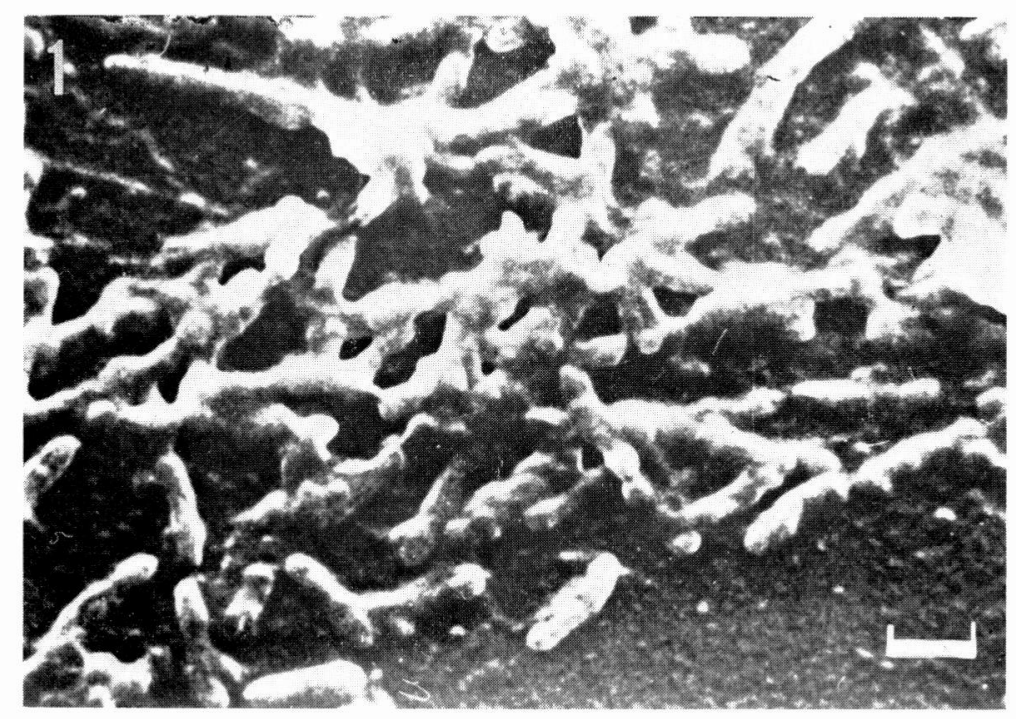

Fig. 1 This shows a part of the smear of $M$. lepraemurium before incubation, in which many granular cell bodies can be seen. $(\times 8,000)$

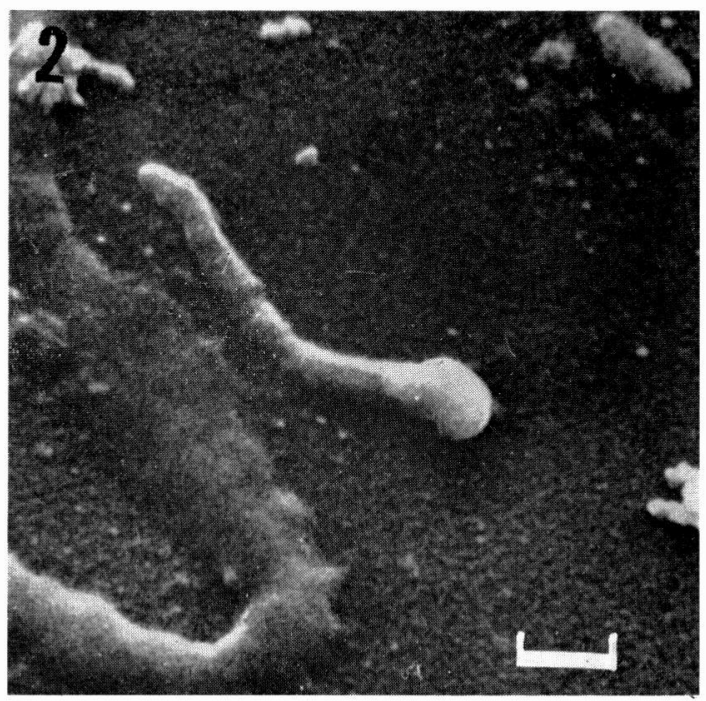

Fig. 2 This shows an elongated cell with a terminal swelling in the period of 4 weeks incubation. The swelling belongs to the round type and its size is about 1.5 times of diameter of bacillar body. $(\times 8,600)$ 


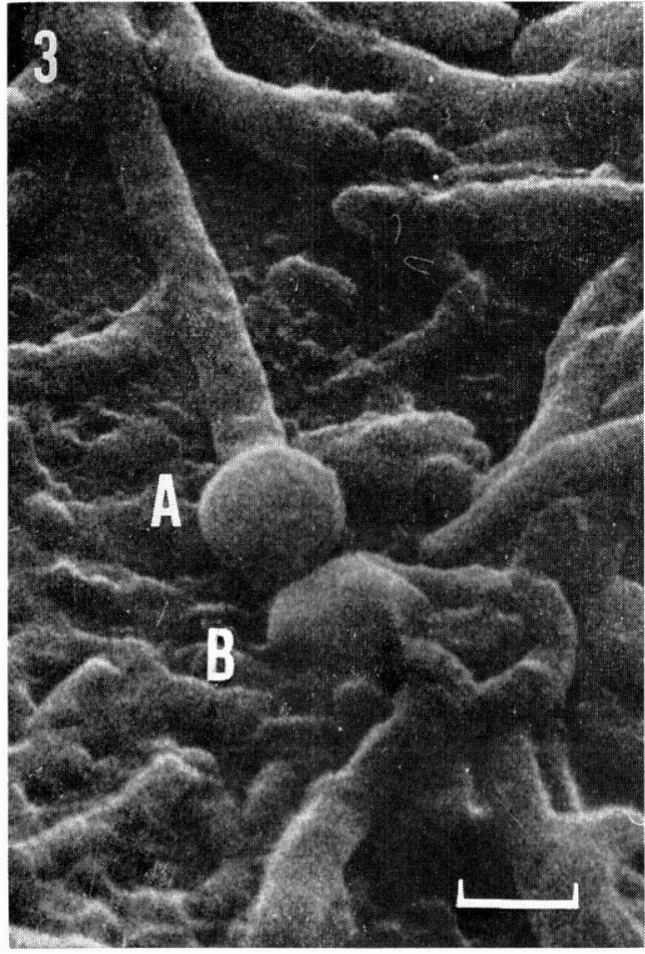

Fig. 3 This shows a part of microcolony at the 6th week of incubation, in which a round type (A) and miscellaneous type (B) can be seen. The round type looks like a free granule. Size of both swellings is about twice in width of other cell bodies in the field. $(\times 14,000)$

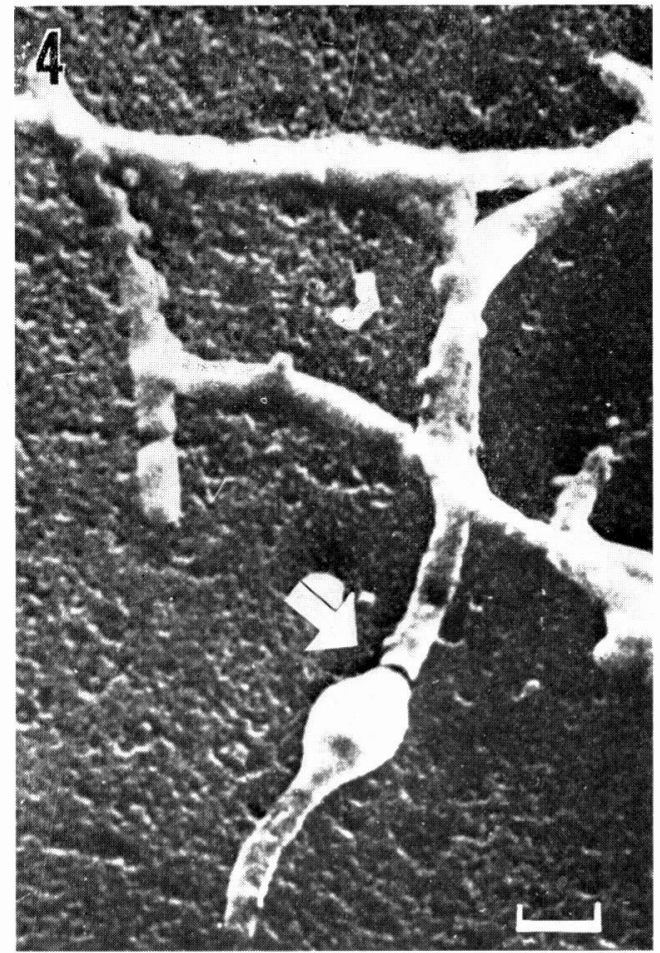

Fig. 4 This shows a kind of branching growth of bacilli with a partial swelling in the stage of 8 weeks incubation. Shape is ellipsoidal and size is about 2.5 times of cell body in which and about $2.0 \mu \mathrm{m}$ in length. A septum between swelling and cell body can be seen (arrow). $(\times 8,600)$ 


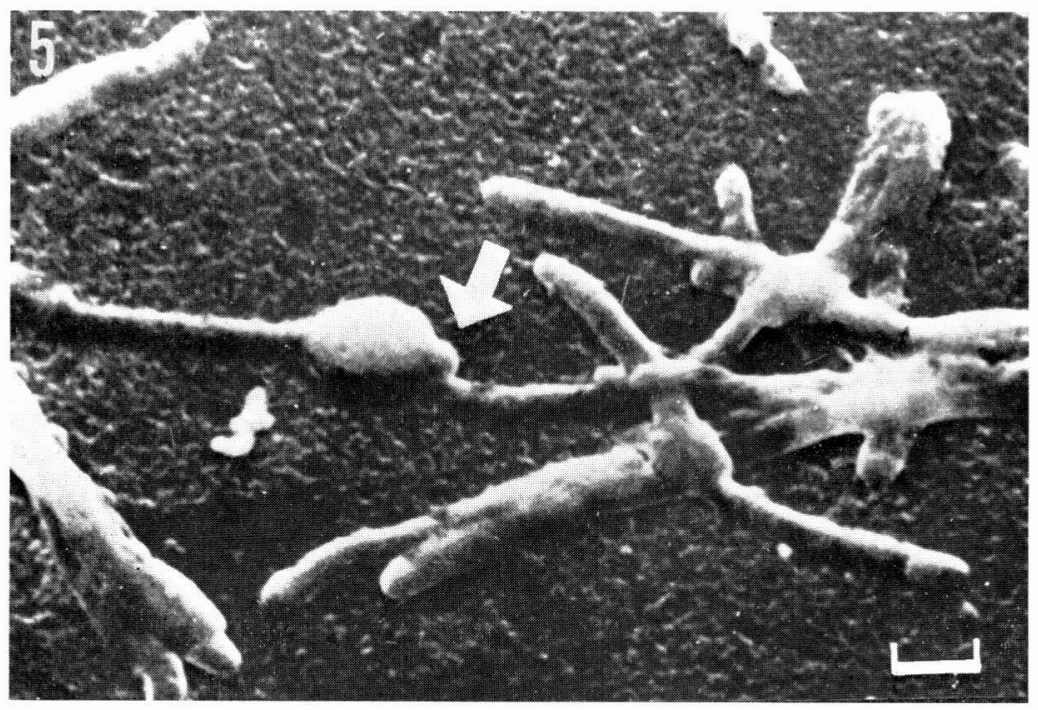

Fig. 5 This shows a partial swelling appeared in the stage of 10 weeks incubation. Shape is ellipsoidal and size is about 3 times of mother cell in width and $1.5 \mu \mathrm{m}$ in length. Location of the swelling is regarded as terminal and a small protrusion (arrow) can be seen in the long direction of cell body. $(\times 8,600)$

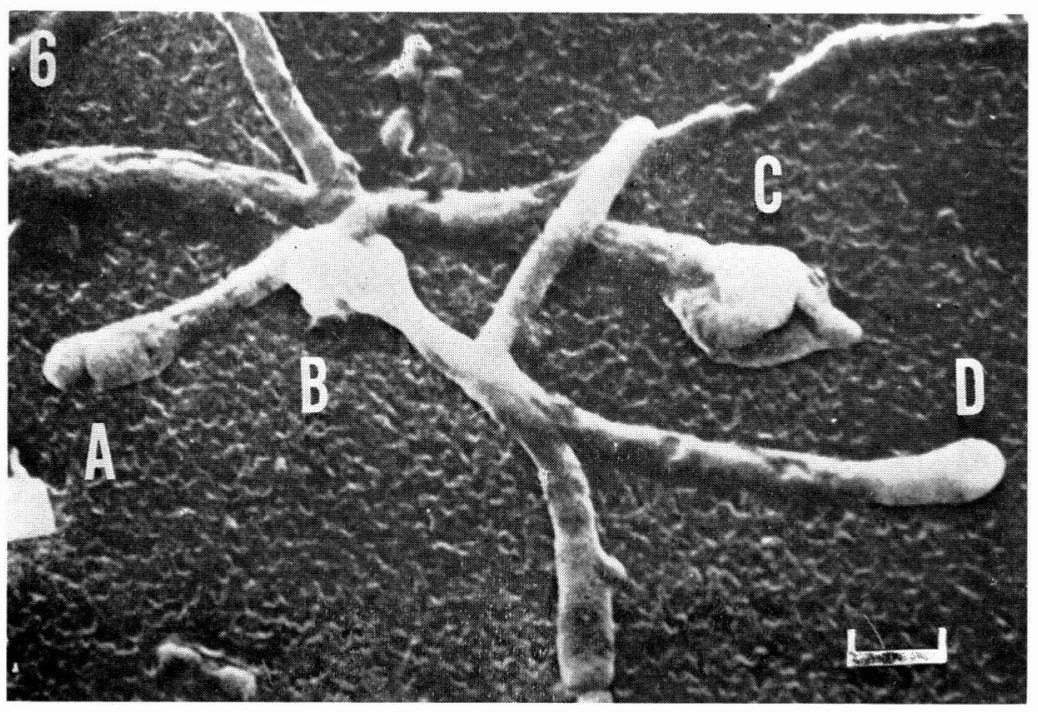

Fig. 6 This shows a kind of branching growth of bacilli with four terminal swellings in the stage of 10 weeks incubation. Swellings (A, B and C) are all miscellaneous shapes, particularly swelling-C is covered with an envelope. Swelling-D locates at the terminal and regarded as a beginning stage of the round type. $(\times 8,600)$ 


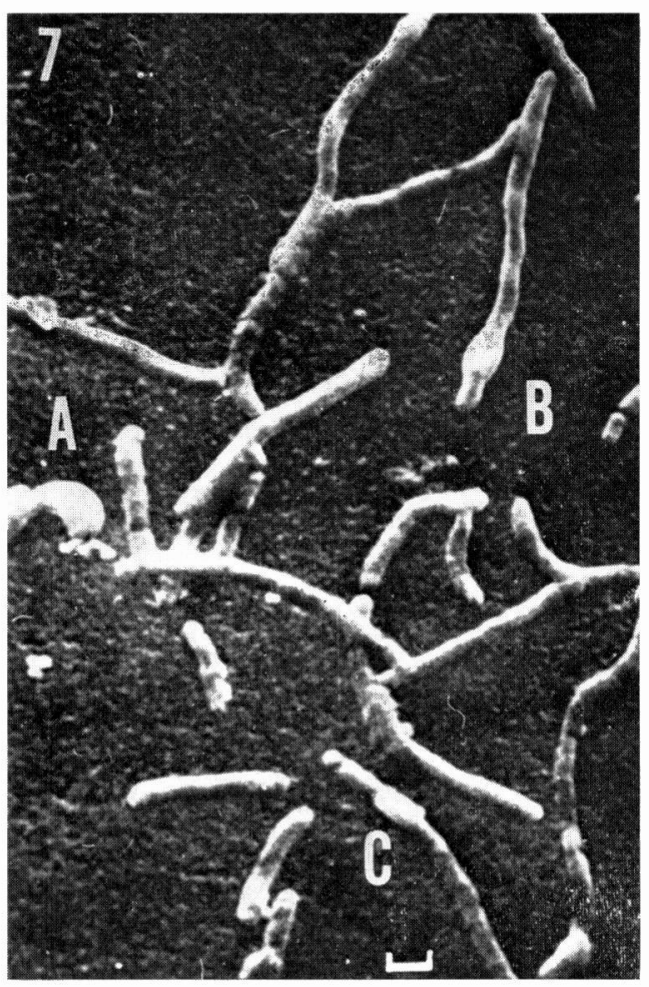

Fig. 7 This shows an area of many growing bacilli with elongation and branching in the stage of 8 weeks incubation. Two types of swellings can be seen. Swelling-A is a free granular type, swelling-B and -C are ellipsoidal and a subterminal types. Size of the latter two ( $\mathrm{B}$ and $\mathrm{C}$ ) is about $1.5 \times 1.0$ and $1.5 \times 0.8 \mu \mathrm{m}$, respectively. $(\times 8,600)$

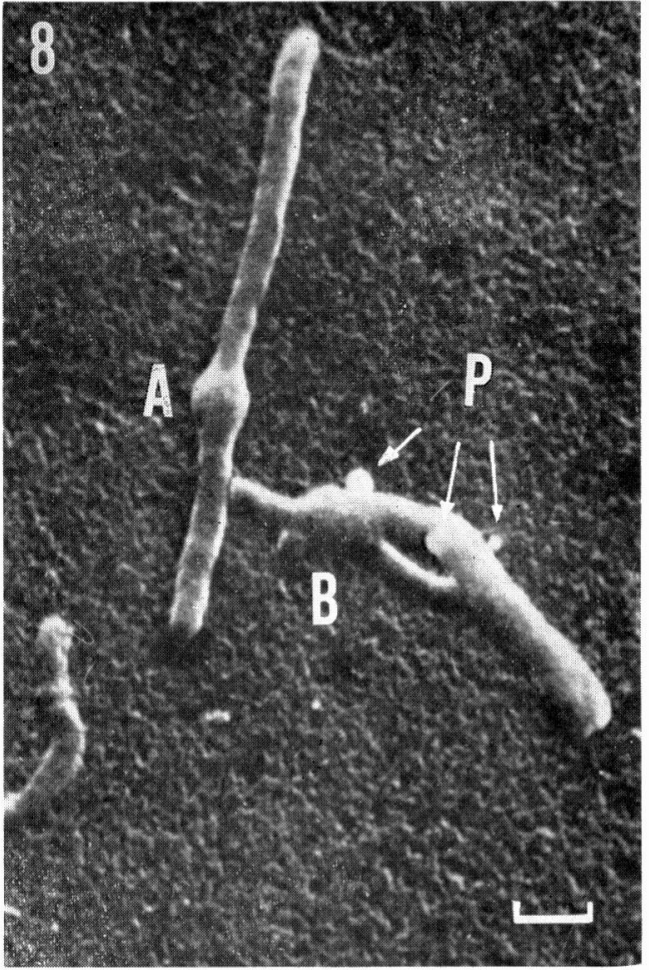

Fig. 8 This shows an elongated cell with branching in the period of 8 weeks incubation. Two partial swellings can be seen in both mother and daughter cells. Size of swelling (A) in mother cell is about $1.0 \mu \mathrm{m}$ in length and twice of cell body in width, and its location is subcentral. The daughter cell shows somewhat complicated status of swelling (B) with four budds (P) and one unidentified branch. $(\times 8,600)$ 


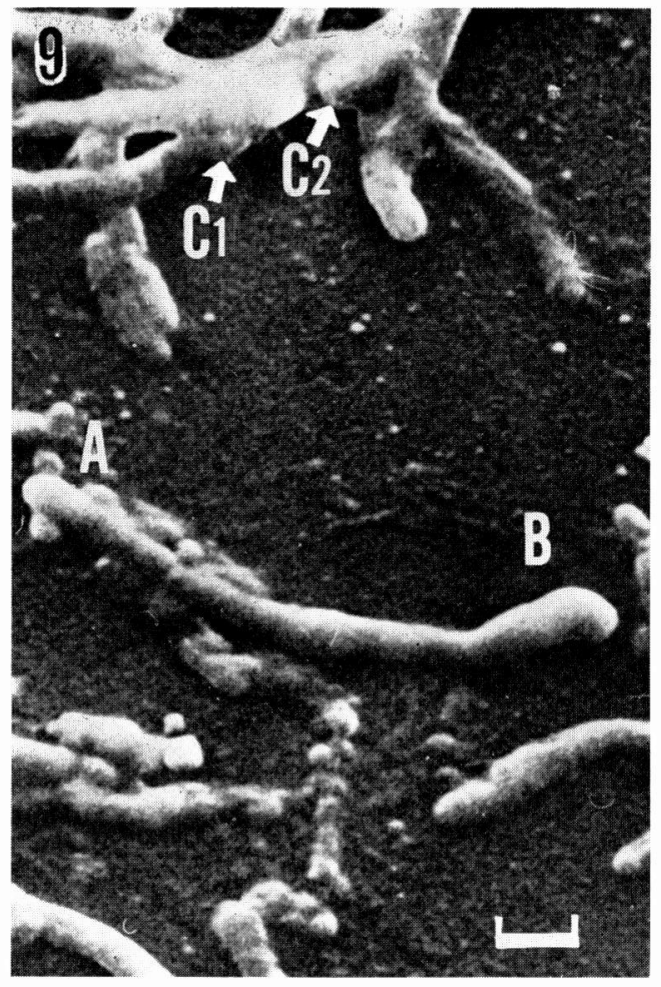

Fig. 9 This shows a bacillar cell with two biterminal swellings in the period of 4 weeks incubation, one (A) is a small ellipsoidal and the other (B) is a long round type. In the above area, a group of growing bacilli with two swellings ( $\mathrm{C} 1$ and $\mathrm{C} 2$ ) can be seen. $(\times 8,600)$

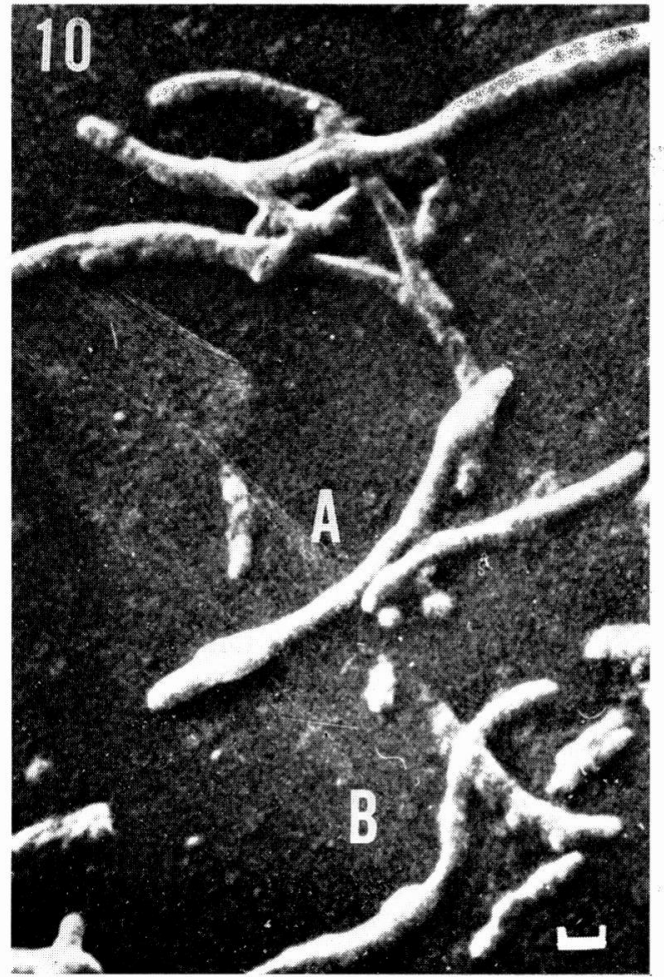

Fig. 10 This shows two cells in the stage of 6 weeks incubation. The cell-A possesses two subterminal swellings in both ends, each of them is ellipsoidal type. Sizes of them are about $2.0 \mu \mathrm{m}$ in length and $1.0 \mu \mathrm{m}$ in width. The other cell-B possesses an incomplete ellipsoidal swelling at the central of cell body and its size is unestimatable. $(\times 4,300)$ 


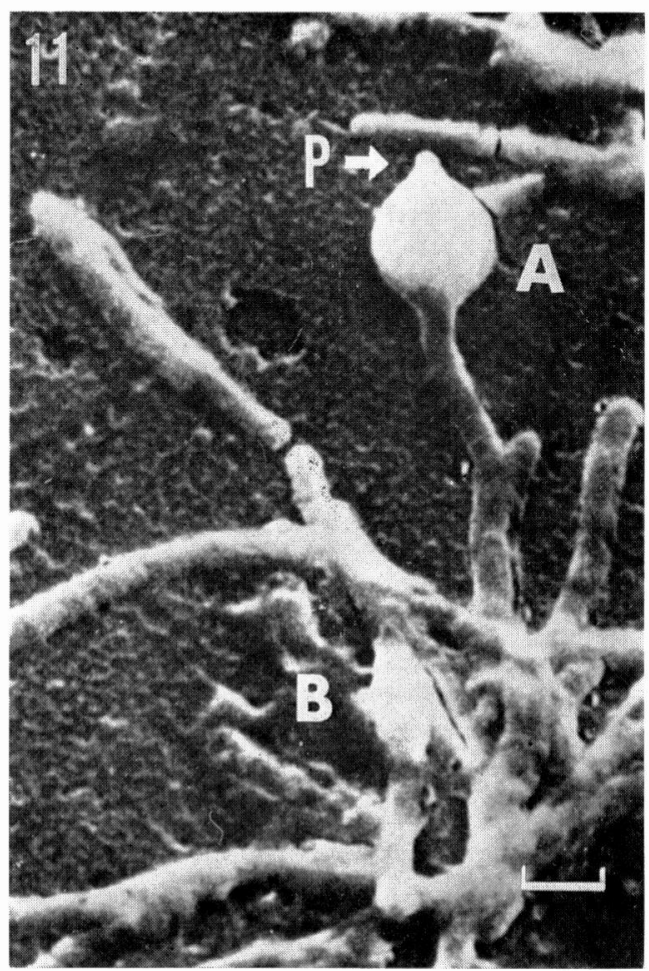

Fig. 11 This shows a large round type and an ellipsoidal type of swelling at the stage of the 10th week incubation. Sizes of swelling are about $1.5 \mu \mathrm{m}$ in length and $1.5 \mu \mathrm{m}$ in width. A small protrusion $(\mathrm{P})$ can be seen in the extensive direction of bacillar cell body. $(\times 8,600)$

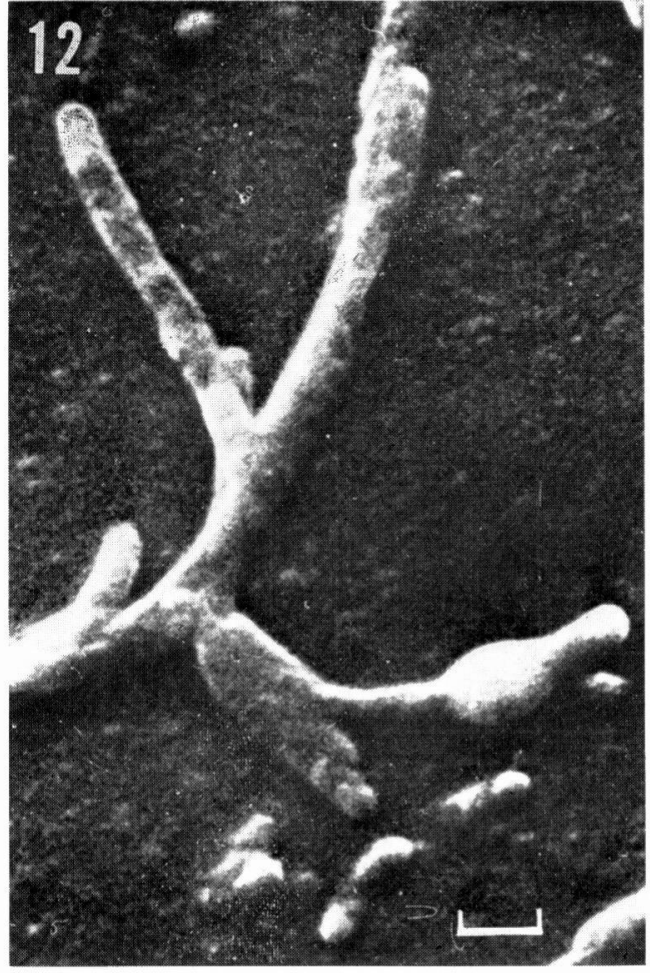

Fig. 12 This shows a branching growth of bacilli, in which one of them possesses an ellipsoidal swelling. Subcentral location of the swelling on the branched cell can be seen. Size of swelling is about $1.8 \mu \mathrm{m}$ in length and $1.0 \mu \mathrm{m}$ in width. $(\times 8,600)$ 


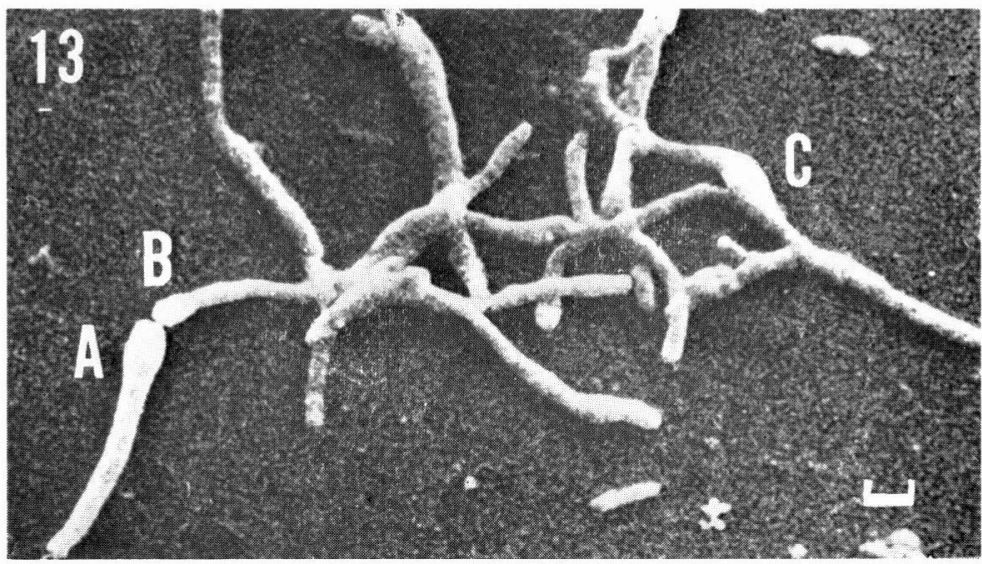

Fig. 13 This shows a beginning stage of microcolonial growth of bacilli in the period of 10 weeks incubation. Three swellings can be seen. Two (A and B) of them are connected each other with small bridge. This connection is regarded as a remnant of separation after division from the viewpoint of general pattern of bacillar growth. The other (C) is considered to be the same as seen in Figure $7 .(\times 4,300)$

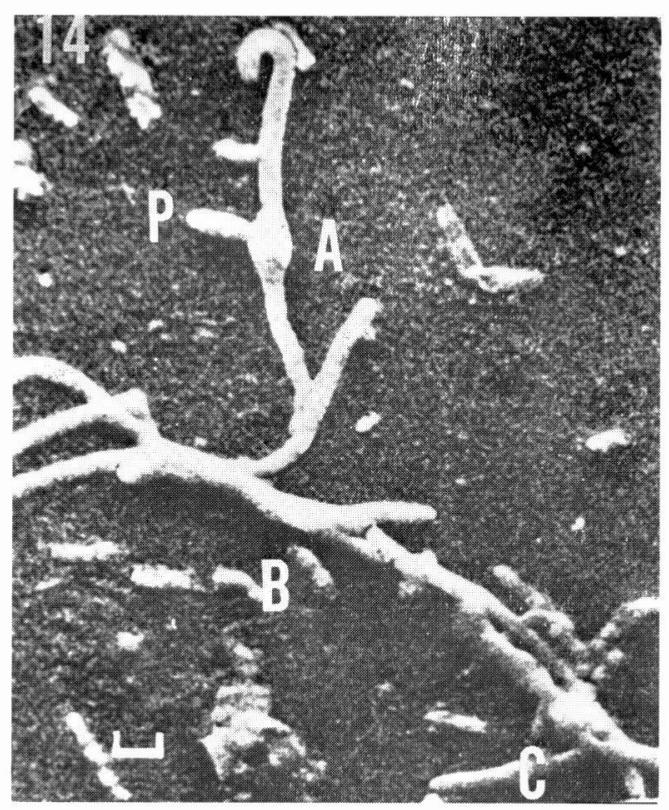

Fig. 14 This also shows a kind of branching pattern of bacillar growth at the 10 th week of incubation. Three swellings (A, B and C) can be seen, and one of them (A) is ellipsoidal type. This swelling is very characteristic, because a side projection $(\mathrm{P})$ from the swelling could be seen and may be a bud from it. $(\times 4,300)$ 